\title{
THE INVESTMENT BANKERS' CASE: SOME OBSERVATIONS
}

\author{
ROSGOE STEFFENì
}

ON October 14, 1953, Judge Medina handed down his opinion in United States $v$. Morgan, ${ }^{1}$ and granted defendants' motions to dismiss the complaint, at the end of plaintiff's case, "with prejudice." The opinion was at once hailed in the press, not only for its soundness, but for providing us with "a textbook on investment banking" to boot: "a freshly vigorous approach to the subject which, one may safely predict, will leave its impress for a long time to come on every work in this field with even the slightest pretensions to scholarship." Even the court is reported modestly to have conceded that his opinion is "a document of literary merit."3

The truth of Judge Medina's further remark, "There is going to be joy"among the bankers, should probably go without saying. The defendants, as their counsel told the court on many occasions, had long chafed under the asserted unfairness of the Anti-Monopoly Investigation into their affairs, which Congress conducted in 1939 and 1940.5 This investigation brought to light for the first time many of the practices, and some of the evidence, upon which the Morgan case was later brought. It does not appear to have been unfair in any other sense. ${ }^{6}$ Witnesses were treated courteously; they had counsel pres-

iProfessor of Law, The University of Chicago. The author was in charge of the Government's case in United States v. Morgan, 118 F. Supp. 621 (S.D.N.Y. 1953), during the investigational stages, and later, in the spring of 1951, took part in the trial. A reply to Professor Steffen by William Dwight Whitney, Esq., one of defense counsel, will appear in a forthcoming issue of the YALE LAW JournaL.

1. 118 F. Supp. 621-832 (S.D.N.Y. 1953).

2. Collins, N.Y. Times, Oct. 19, 1953, p. 29, col. 5.

3. United Press report printed in the Chicago Daily News, Oct. 15, 1953. Judge Mfedin is there reported also to have said: "My opinion is a complete history of the American investment banking business, and as an anti-trust opinion it is unique in that it does not deal in generalities."

4. Ibid.

5. See TNEC, Investigation of Concentration of Econosic Power (TNEC Monographs 22-4, 1940-1).

6. To the extent that defendant's claim of unfairness has any point, it rests upon the committee's refusal to take evidence on the supposed evils of competitive bidding for securities, and concerning the practices of large institutions in buying directly from issuers, at so-called "private placement." These were giving serious concern to defendant bankers, who thought their way of doing business by private negotiation with the issuer, and without price-competition, was more in the public interest. The committee decided, and it would seem reasonably, that such matters were outside the scope of its immediate investigation. For a comparison of the purchase of securities by "negotiation" and by "competition," see Atkins, Edwards, \& Mroulton, The Regulatton of tae Security Markets 99 et seq. (1946). 
ent; they were permitted to answer questions fully and in their own way. By post-1952 standards, ${ }^{7}$ the Committee may have been guilty of "coddling" witnesses, so to speak, but not of unfairness.

But the evidence did put investment bankers in a bad light, so far at least as the antitrust laws are concerned. The joining of erstwhile competitors into syndicates on an "historical" basis, the reciprocal granting of buying group participations, all with no price-competition either in the purchase of securities, or in their resale, seemed to fly in the face of the Sherman Act. Hence, Judge Medina's holding undoubtedly was quite well received. No time was lost, in fact, before several thousand copies of his opinion, which was 424 pages long, were specially printed for distribution to issuer-clients and others. ${ }^{8}$ Here, at last, was vindication, even though it might be short-lived.

Defendants must have known that there have been other long and quite as scholarly trial court opinions, which have not survived appeal. Judge Caffey's holding in $A l c o a,{ }^{9}$ and that of Judge Stephens in the Gypsum ${ }^{10}$ case, come to mind. Perhaps the defendants took seriously Mr. Dooley's famous line about law and the election returns. But, however that might be, Assistant AttorneyGeneral Barnes, after due consideration, ${ }^{11}$ decided to let the deadline pass for filing an appeal. "We're not interested in taking an appeal on a lost cause," he said. "We're not going to throw away money to justify a previous position where the Government has, in the opinion of the trial court, overextended itself." 12

Thus, more or less by default, Judge Medina's holding has become the "law" of the land, and in a very important segment of the economy. For it is vital to legitimate enterprise that it have a completely free market in which to sell its securities to investors. ${ }^{13}$ No self-appointed group, however worthy its mo-

7. For example, those of McCarthy, Jenner, Velde, and Reece, in the present Congress.

8. Published by the Record Press, New York. Price to the public, $\$ 8.00$ per copy.

9. United States v. Aluminum Company of America, 44 F. Supp. 97-311 (S.D.N.Y. 1941), rew'd, 148 F.2d 416 (2d Cir. 1945).

10. United States v. United States Gypsum Co., 67 F. Supp. 397-517 (D.D.C. 1946), rev'd, 333 U.S. 364 (1948).

11. The trial staff was unanimously in favor of an appeal, although they differed as to scope. The appellate section, as is its wont, took a dim view of any appeal. When asked his views, the writer submitted on March 8,1954, well ahead of the deadline, a memorandum favoring an across-the-board appeal substantially on the basis discussed in this paper.

12. Judge Barnes' comment, as reported in the Wall Street Journal, April 8, 1954, p. 1, col. 3. It should not be taken, I am sure, as a matured statement of Antitrust Division policy; in fact, it would seem to be faintly tinged with politics.

13. The Securities Act and related legislation was designed primarily to protect the investor. There is no suggestion that the SEC was charged with responsibility to enforce the Sherman Act. The principal, if not the only, power of the Commission to bring about competitive conditions in the industry was granted it by the Public Utility Holding Company Act of 1935. And the Commission exhausted its power in that regard, as the Commission itself said in Release No. 3700, 11 SEC ANn. REp. 918 (1942), when it adopted Rule U-50, requiring competitive bidding for the securities of those companies subject to that Act. 
tives, ${ }^{14}$ may be permitted either to limit or to postpone access to that market. or to $\operatorname{clog}$ its operation by restraints upon prices or methods of sale. And it is not enough, or even relevant, that the banker can say that our economy has developed and prospered in the past: it may well have done so, but at an unwarranted cost in terms of restraint of trade.

Fortunately, though, we are assured by Judge Medina-and Judge Barnes concurs ${ }^{15}$ - that there have been no improper restraints in the securities business, or, at least, that Government counsel in the course of a long trial were unable to show any. The matter is of such importance, however, that it is proposed in what follows to look first to the charges, as precisely alleged in the complaint, and then to examine carefully how the court disposed of them. It may be that, instead of the Government having a "lost cause," its prima facie case was actually fully established. Perchance the trial court ruled on "some other case" than the one alleged in the complaint.16

\section{The Restraint of Trade Charged.}

The heart of an antitrust pleading-whether by indictment or complaint-is the charging paragraph. This states in few words the nature of the offenses charged. Where the offense is conspiracy in restraint of trade under Section 1 of the Sherman Act, the nature of the restraint, such as price-fixing, "17 controlling distribution, ${ }^{18}$ dividing markets, ${ }^{10}$ or whatever, is briefly stated. Perhaps the charging paragraph alone would suffice. But at least since the Sicioft case,, 0 it has been customary to precede the charge with a comprehensive description of the industry and of the commerce alleged to be restrained, and to follow it with a recital of some of the means by which the offense is alleged to have

14. The Supreme Court has said many times that good intentions are no substitute for the declared policy of Congress. See, c.g., Standard Sanitary MIfg. Co. v. United States, 226 U.S. 20 (1912).

15. The Solicitor General, Judge Sobeloff, should perhaps also be included, since he had the final responsibility.

16. It is a separate question, not discussed nor particularly important here, whether the trial court's findings of fact are well supported. In United States v. Yellow Cab Co., 338 U.S. 338 (1949), and United States v. Oregon State Medical Soc'y, 343 U.S. 326 (1952), the Supreme Court made it plain that it is reluctant to go back into the record to determine whether a trial court has weighed the evidence as the appellate court would have done. But manifest error of law is a horse of a different color. The Court should be particularly anxious, it would seem, to see to it that the standards used by the trial judge were correct, even if this might require an extensive examination of the record.

17. United States v. Socony-Vacuum Oil Co., 310 U.S. 150 (1940).

18. Eastern States Lumber Dealers' Ass'n v. United States, 234 U.S. 600 (1914).

19. United States v. Trenton Potteries, 273 U.S. 392 (1927).

20. Swift \& Company v. United States, 196 U.S. 375 (1905). See, garticularly, the language of Mr. Justice Holmes. Id. at 395-6. The Surift case was much like the Morgan case. Both dealt with alleged restraints upon distribution, beef in one case and bonds in the other. The packers did not form syndicates to buy cattle, but they had other devices, which, it was alleged, were well calculated to eliminate price-competition and reduce prices to growers. 
been carried out, together, of course, with a prayer for relief. It is thus-in essence-a very simple pleading.

The complaint in the Morgan case followed precedent. In Paragraph 43, the charging paragraph, the defendants are alleged to be engaged "in a wrongful ... conspiracy to restrain ... the securities business . . . by restricting, controlling, and fixing the channels and methods through which, and the prices, terms, and conditions, upon which security issues are merchandized ...."21 The alleged conspiracy in restraint of trade, thus, has to do with distribution, the purchase and sale of securities. It is alleged to be wrongful in two respects : (1) securities have been made to flow in controlled channels; (2) prices have been fixed and maintained.

That is the conspiracy in restraint of trade-and the only such conspiracycharged in the complaint. In Paragraph 44A, some of the "means" are stated by which the defendants are alleged to have agreed "not to compete among themselves" in carrying out the conspiracy charged in Paragraph 43. The first of these, alleged in Paragraph 44A(1), is the use by defendants of "the syndicate method to merchandise ... security issues ...." The statistical data in the case shows-without contradiction-that the seventeen defendant bankers, by use of the syndicate method, managed over seventy percent of all issues of $\$ 1,000,000$ or more which were offered publicly on a negotiated basis during the fifteen year period from 1935 to 1949 . Stated quantitatively, the seventeen defendant bankers managed security issues aggregating $\$ 17,337,087,000$ out of a total for the period of $\$ 23,673,017,000$, a very substantial commerce, indeed.22 For reasons by no means clear the court made no mention of these facts in his opinion.

In Paragraph 44B, the "means" are stated by which the defendants are alleged to have agreed "to eliminate the competition of other investment

21. The full text, under the caption "Offenses Charged," is as follows: "43. Beginning in or about the year 1915 and continuing thereafter up to and including the date of the filing of this complaint, the defendants named herein, have engaged knowingly and contintously, in a wrongful and unlawful conspiracy to restrain unreasonably and to monopolize the securities business of the United States, by restricting, controlling, and fixing the channels and methods through which, and the prices, terms, and conditions, upon which security issues are merchandised, and have, in fact, unreasonably restrained the securities business hereinbefore described, and have monopolized the merchandising of sectrity issues therein by the negotiated underwritten method, all in restraint and in monopolization of the interstate commerce described in this complaint, in violation of Sections 1 and 2 of the Act of Congress of July 2,1890, entitled 'An act to protect trade and commerce against unlawful restraints and monopolies,' as amended, commonly known as the Sherman Act (15 U.S. C.A. $\$ \S 1$ and 2). Defendants threaten to continue such offenses and will continue them unless the relief hereinafter prayed for in this complaint is granted."

Paragraph 43 was not changed, abandoned or modified in any way, throughout the case, except only that on April 9, 1951, before any evidence was introduced, the words, "by the negotiated underwritten method," were added in the interest of supposed greater clarity. See United States v. Morgan, 11 F.R.D. 445 (S.D.N.Y. 1951).

22. Exhibit 11.1(f), Transcript of Record, p. 7806, United States v. Morgan, $118 \mathrm{~F}$. Supp. 621 (S.D.N.Y. 1953). 
bankers" in carrying out the conspiracy. ${ }^{23}$ This part of the case was largely based on the fact that the defendant bankers, as managers of so large a part of the new-issue business, have been able to grant participations in their syndicates to other bankers, or to exclude them from underwritings, very much as they saw fit. In fact, the syndicate is beautifully contrived as a safety valve to prevent any unseemly competitive explosion. Bankers posing a small competitive threat may be given a syndicate participation or their position in the last underwriting may be improved; those who because of friendship with the issuer or for some other reason might unseat the established manager may be given a joint managership.

The evidence showed that, as a first step in the use of the syndicate method, each of the defendants has long done business by getting himself named as banker-whether traditional, regular or otherwise-for one or many issuers. He then acts as a professional adviser, much as a lawyer or an accountant does, in getting an issue ready for public offering. But there the comparison ends. Unlike the lawyer or the accountant, the defendant banker customarily works without fee. He plans to make his money out of the purchase and resale of the securities themselves, when they are ready for market. ${ }^{21}$

This was the core of the Government's case. ${ }^{25}$ In legal language, defendant bankers were charged with using a service or professional relationship as a means of doing a vast merchandising business in securities, with the purpose and effect of controlling distribution channels and eliminating price-competition. ${ }^{20}$ Moreover, the record leaves no real doubt that defendant bankers do just that. They point with pride to the services they perform for their

23. This was a relatively minor term of the conspiracy in restraint of trade, and hence. whether established by the evidence or not, was of little conseguence. It was critical, of course, to the counts of Paragraph 43 charging (1) a monopoly and (2) a conspiracy to monopolize. After finding no conspiracy in restraint of trade, that is, no "integrated overall conspiracy," the court dismissed the monopoly charges without discussion. United States v. Morgan, 118 F. Supp. 621,829 (S.D.N.Y. 1953).

24. See, e.g., the deposition testimony of C. E. Mitchell of Blyth \& Co., Transcript of Record, p. 6958, United States v. Miorgan, 118 F. Supp. 621 (S.D.N.Y. 1953).

25. One of the principal items of relief requested in the complaint was the separation of the advisory functions of the banker from those of merchandising. See Prayer for Relief, paras. 2, 4, United States v. Morgan, 118 F. Supp. 621 (S.D.N.Y. 1953). This was pointed out to the court many times. See e.g., Transcript of Record, p. 4794 ct seq., United States v. Morgan, 118 F. Supp. 621 (S.D.N.Y. 1953).

26. The "law" of the case was never much in doubt, although, in the nature of things, there was no precedent exactly on all fours. For the unlawfulness of using a service monopoly to control merchandising, the case of United States v. Pullman Co., 50 F. Supp. 123 (E.D. $\mathrm{Pa}$. 1943), was called to the court's attention; as to the effect of narrowing retail outlets, Fashion Originators' Guild v. Federal Trade Comm'n, 312 U.S. 457 (1941) ; upen controlling prices to the issuer, Mandeville Island Farms, Inc. v. American Crystal Sugar Co., 334 U.S. 219 (1948) ; United States v. Swift \& Co., 52 F. Supp. 476 (D. Colo. 1943) ; upon maintaining resale prices, Dr. Milies 1 redical Co. v. Park \& Sons Co., 220 U.S. 373 (1911). See generally, Berle, Banking Under the Antitrust Laus, 49 CoL L. Rav. 589 (1949). 
clients. ${ }^{27}$ They do not engage in price-competition, as will be discussed more fully later on, either in the purchase or the sale of securities. On one memorable occasion, in fact, learned counsel for one of the defendants went so far as to suggest to the court that anyone would be a "stinker,"28 who would offer an issuer a better price under such circumstances.

But, in Paragraphs 44A(2), (3) and (4), the Government went farther. First, it was alleged that many such banker-client relationships are recognized by defendant bankers as "traditional." If established, this would mean that the defendants have even eliminated competition at the first step, that is, as to the selection of a banker and in the formulation of financing plans. Secondly, it was alleged that, by use of the "historical position" concept, many syndicates have become more or less static from issue to issue, thus still further limiting the issuer's market, and affecting the prices at which he might sell his securities. Thirdly, by "reciprocity," defendants are alleged to have given participations to each other on the basis of participations received or expected. In other words, by use of a sort of financial patronage, defendants are alleged to have built up a wide network of noncompetitive relationships in the industry. Most of the evidence in the case bore on these "triple concept" allegations. But they were merely the $a$ fortiori parts of the case.

The fifth "means," Paragraph 44A (5), had to do with resale prices. There is almost no fact dispute that in hundreds of syndicates, with anywhere from one to fifteen or more of the defendants associated together as participants, it has been agreed to maintain the public offering price for varying lengths of time, at defendants' sole discretion. Likewise, dealers have been required to maintain resale prices; sales through others than syndicate or selling group members have been prohibited, except when made at a fixed re-allowance; and, issue after issue has been stabilized, all more or less as defendants have thought best. Whether any one of these agreements would have been illegal in itself, as seems likely, may be disregarded for the moment; they were offered primarily as part of the proof showing that defendants had agreed to eliminate pricecompetition among themselves in the conspiracy charged in Paragraph 43.20

27. See, e.g., the testimony of Walter E. Sachs, when testifying upon cross-examimtion as to the "service" his firm had performed for the May Company. Transcript of Record, pp. 6850-5, United States v. Morgan, 118 F. Supp. 621 (S.D.N.Y. 1953).

28. Transcript of Record, p. 5262, United States v. Morgan, 118 F. Supp. 621 (S.D. N.Y. 1953). The Government's charge, that the defendants have agreed not to compete price-wise in the purchase of securities from issuers, was described in this way: "That is nothing more nor less than an agreement not to be 'stinkers.'"

29. Since defendants manage so large an amount of the new-issue business, and include large numbers of non-defendants, as well as defendants, in their syndicates, this was, in effect, a charge of no price-competition throughout the industry. Of course a new issue, however brought out, must sell in competition with the general mass of outstanding securities, previously issued. That was not in question. The case was directed at four price restraints upon the flow of new securities into the general market: (1) the absence of competition in negotiating prices to issuers; (2) maintenance of public offering prices by syndicate members throughout distribution; (3) price restrictions upon resale by dealers; and 


\section{No Unifying Element}

The court's opinion is largely given over to an examination of the evidence in the case. But at the outset reference is made to the memorandum of April 9, 1951 , in which the court pointed out that, as he then saw the case, "the unifying elements of the alleged conspiracy were obscure," to say the least." This memorandum was written after months of discussion during the opening statements of counsel, and only shortly before the Government started to introduce its evidence. ${ }^{31}$ Though "puzzled," the court was careful to say further that he did not mean that "absent a 'unifying element' . . . there can be no agreement or conspiracy," but merely that in such case he should "proceed cautiously" in viewing the evidence. ${ }^{32}$

What the court meant by "unifying element," is fairly clear. The opinion goes on to say by way of illustration: "no industry-wide uniformity was charged;" there was "no powerful group such as the 'Big Three' operating against independents," as in the American Tobacco ${ }^{33}$ case; there was "no letter or series of agreements presenting a definite plan to which others might consciously adhere," as in the Interstate Circuit ${ }^{34}$ and MLasonite ${ }^{35}$ cases; and, "there appeared to be many non-defendant investment banking firms which were larger, had more capital and did more business than some of the defendants."30 On the other hand, the court said several matters, which might have served as "possible unifying element [s]," such as common membership in the Investment Bankers Association, the keeping of reciprocity records, or the invention of the syndicate system, had either been abandoned or disproved.

Of course, it is a commonplace that the presence or absence of conspiracy must be determined by an examination of all the circumstances. It cannot be determined by the application of some mechanical formula, nor is there any authority that, in the absence of a so-called "unifying element," the court must proceed with extra caution. The "unifying elements" in the cases cited by the court (the agency contracts in Masonite, the letters in Intcrstate Circuit) were simply evidentiary circumstances present in those cases. In neither did that factor in itself reflect or constitute the conspiracy. The same, it may be said, is true with respect to the license agreements in the Gypsum case, ${ }^{3 i}$ the fran-

(4) stabilization of the public offering price. See the Government's "Mfemorandum on Price-Fixing," p. 2 et seq., submitted in March, 1951, Transeript of Record, United States v. Morgan, 118 F. Supp. 621 (S.D.N.Y. 1953).

30. United States v. Morgan, II F.R.D. 445 (1951).

31. The trial started on Nov. 2S, 1950, but it was not until Mfay 1, 1951, that the court received any evidence. The intervening period to April 2, 1951 was given over to opening statements, in very large part by defense counsel.

32. United States v. Miorgan, 11 F.R.D. 445, 456 (1951).

33. American Tobacco Co. v. United States, 328 U.S. 781 (1946).

34. Interstate Circuit, Inc. v. United States, 306 U.S. 208 (1939).

35. United States v. Masonite Corp., 316 U.S. 265 (1942).

36. United States v. Morgan, 118 F. Supp. 621, 632 (S.D.N.Y. 1953). This last statement is both ambiguous and irrelevant.

37. See note 10 supra. 
chise agreement in the Paramount ${ }^{38}$ case, and the Communist Party in the Dennis ${ }^{39}$ case.

The Supreme Court has never reversed a finding of conspiracy, or approved a refusal to find one, on the ground that a mechanical unifying element of the kind sought by the court was either essential to a conspiracy or necessary to prove one. The true test of conspiracy is the existence of a unity of purpose to accomplish an unlawful object. ${ }^{40} \mathrm{Or}$, as more fully spelled out in the antitrust field, it is an association or understanding between erstwhile competitors according to a common plan or design, "the necessary consequence of which, if carried out, is restraint of interstate commerce."41 No mechanical or tangible central fulcrum is needed. Likewise, as a matter of proof, it is sufficient if the evidence, either direct or circumstantial, when viewed in its entirety, rather than piecemeal, establishes the existence of such a unity of purpose or common design.

What exact effect the absence of a so-called "unifying element" may have had in bringing the court to dismiss the case, is of course difficult to say. The unsuccessful search for a mechanical element tying the defendants together appears, however, wholly to have obscured for the court the actual charge of conspiracy as alleged in the complaint, that is, that the defendant bankers are associated or tied together in a common plan and purpose to eliminate pricccompetition in the purchase and sale of securities and to channelize distribution. The opinion is written - and presumably the case was decided-as though these matters had very little to do with the case.

\section{Integrated Over-all Conspiracy}

Judge Medina does not make an analysis of the several counts alleged in Paragraph 43 of the complaint. ${ }^{42}$ Rather, he paints a broad impressionistic picture of the case. Thus, under the heading: "The Offense as Charged in the Complaint," the two counts charging first a conspiracy to restrain trade and

38. United States v. Paramount Pictures, 334 U.S. 131 (1948).

39. United States v. Dennis, 183 F.2d 201 (2d Cir. 1950), aff'd, 341 U.S. 494 (1951).

40. The remarks of Mr. Justice Holmes in United States v. Kissel and Harned, 218 U.S. 601,608 (1910) are interesting: "A conspiracy is constituted by an agreement, it is true, but it is the result of the agreement, rather than the agreement itself, just as a partnership, although constituted by a contract, is not the contract but is a result of it." Sec also Duplex Printing Co. v. Deering, 254 U.S. 443 (1921); Direct Sales Co. v. Unitcd States, 319 U.S. 703 (1943).

41. Interstate Circuit, Inc. v. United States, 306 U.S. 208, 227 (1939).

42. These were carefully described as being four in number: (1) a count based on conspiracy to restrain trade; (2) a count on actual restraint; (3) a count on conspiracy to monopolize; and, (4) a count charging an actual monopolization. See Transcript of Record, p. 4469, United States v. Morgan, 118 F. Supp. 621 (S.D.N.Y. 1953). That the first two counts constitute separate offenses, under Section 1 of the Sherman Act, and the last two, separate offenses under Section 2, is well settled. See, e.g., discussion in Montrose Lumber Co. v. United States, 124 F.2d 573 (10th Cir. 1941); United States v. A. B. Dick Co., 7 F.R.D. 437 (N.D. Ohio 1947). 
secondly a conspiracy to monopolize are simply run together and described as constituting one single offense. As the court put it: "The complaint charges an integrated over-all conspiracy ... by which the defendants as a group 'developed a system' to eliminate competition and monopolize 'the cream of the business' of investment banking." 13

Of course, there is no "conspiracy" known to the law-integrated, over-all or otherwise-which comprises both "monopoly" and "restraint of trade." But, as appears a few pages later, such was the offense charged, as the court saw it: "Thus it is the 17 defendant banking houses, arrayed against the balance of the investment banking industry, and alleged to be acting in combination to monopolize 'the cream of the business,' and divide it up among themselves, by excluding those investment banking houses which are not part of the conspiracy."

Contrary to the court's statement, this "cream of the business" language does not appear in the complaint. The improvisation was perhaps harmless enough as applied to the monopoly aspects of the case. There, indeed, the seventeen defendants are alleged to be arrayed against the industry. But, as applied to the conspiracy to restrain trade, it gave a seriously distorted view. The main thrust of that conspiracy, as pointed out above, was stated in Paragraph 44A: it consisted first and foremost of an alleged agreement among the defendant bankers "not to compete among themselves." Whether the defendants by so doing would be able to get or hold the "cream of the business" from the rest of the industry was wholly beside the point.

How the court came to fall into such an error is not clear; probably it occurred at some time during the opening statements, when defense counsel were permitted to talk at great length on many subjects. By the time the memorandum of April 9, 1951 was written, the idea evidently had become firmly fixed in the court's mind: "Despite the references to testimony and documents to be produced and the prolonged discussion pro and con, I ann still in the dark as to what will constitute the unifying element or other nexus which is to place these defendants, perhaps with a few investment banking firms more or less, in a conspiracy or combination to restrain or exclude the competition of the rest of the investment bankers and to monopolize the business or any part thereof to the detriment of such other investment bankers." 15

Such a construction of Paragraph 43, of course, is not only unique; it is manifest error. ${ }^{46}$ It would make no difference in the court's view to what ex-

43. United States v. Morgan, 118 F. Supp. 621,629 (S.D.N.Y. 1953).

44. Id. at 632 .

45. United States v. Morgan, 11 F.R.D. 445, 454 (1951) (italies added).

46. The Government in its "Memorandum on the Over-All Conspiracy" submitted on Miay 29, 1951, Transcript of Record, p. 7942, United States v. Mlorgan, $11 S$ F. Supp. 621 (S.D.N.Y. 1953), carefully described "the conspiracy in restraint of trade" for the court, as "one" only of the "four counts" stated in Paragraph 43 of the complaint. The use of "over-all" was to emphasize the point that the complaint was not directed at any particular syndicate operation. The idea of an "integrated" conspiracy, part monopoly and part restraint of trade, originated with the court, quite possibly aided by defense counsel. 
tent the defendant firms might be shown unlawfully to have conspired to restrain competition as between themselves. The case would be dismissed unless it could also be shown that the conspiracy had the monopoly effect of eliminating the competition of other investment bankers, so that the seventeen could have "the cream of the business" themselves. The court, therefore, seems to have added something quite new to the Sherman Act-without congressional sanctionan "integrated over-all conspiracy," made up, presumably in equal parts, of restraint of trade, under Section 1, and of monopoly, under Section 2.

\section{Invention of the Syndicate System}

The charge being thus defined, the court turned to the evidence. Who invented "The Syndicate System" next became a question of great moment. Early in the trial, as above noted, Judge Medina had regarded that as a possible "unifying element," for, as he says: "it was claimed that defendants and their 'predecessors' had invented the syndicate system to further their plan and scheme." 47 And, to a point, the court was right, for it is alleged in Paragraph 27 of the complaint, as part of the description of the industry, that "the modern syndicate method of distributing securities was invented by defendant banking firms and their predecessors in 1915 and . . . modified by them from time to time in details."

But, invention of "the syndicate system," was never alleged to be a "unifying element." It was the use of the syndicate method-regardless of who invented it-which was put in issue. That was alleged in Paragraph $44 \mathrm{~A}(1)$ to be one of the several "means" employed by the defendants in carrying out the restraint of trade conspiracy charged in Paragraph 43. Yet there is no indication, throughout a long opinion, that the court ever examined the syndicate method evidence for its bearing on the charge that the defendants had agreed to eliminate pricecompetition and to channelize distribution. On the contrary, having become persuaded that the defendants were not the sole inventors of the system, and so, that the system could not serve as a "unifying element," he simply put it to one side.

Certain excerpts from the opinion are illuminating. On the basis of about 1,300 "syndicate agreements" in evidence, the court stated that "they contain a great variety of provisions relative to price maintenance, the trading account or stabilization, withholding commissions (the so-called 'penalty' clauses), uniform concessions and reallowances, authorizations to the manager to act for the group in such matters as group sales, dealer sales, syndicate and price termination, extension or price reduction, and so on." $48 \mathrm{Or}$, as he put the thing shortly: "There is a conspicuous lack of uniformity." 40 Of course, the court said, there is "a certain fundamental similarity in those features which are characteristic of the system." ${ }^{\circ}$ How could it be otherwise, in view of "the

47. United States v. Morgan, 118 F. Supp. 621, 632 (S.D.N.Y. 1953).

48. Id. at 683 .

49. Ibid.

50. Ibid. 
evolution of the syndicate system over the years" "' And, while defendant banking firms, "motivated solely by normal, ordinary business considerations," as the court put it, were said to have "played their several parts" in the "evolution of the syndicate system," they were not alone, for "other prominent and leading investment banking houses" also played an unspecified part in the creation." Hence, the court concluded: "There was, with reference to the development and use of the syndicate system, no concert of action, no agreement and no conspiracy, integrated, over-all or otherwise." 53

Such a sweeping finding would be impressive if it stood alone. The court, however, made plain the two standards by which he evaluated the evidence upon which it rests: (1) was there such "uniformity" in the forms as to show connivance; and, (2) did the defendants alone invent "the syndicate sy'stem"? The first test was erroneous, since it was not charged-as a nexus of the conspiracy - that the defendants ever agreed or conspired to write "uniform" syndicate agreements. Secondly, as pointed out above, it is wholly immaterial that some other banker or bankers may also have had a part in developing the system. Hence, the court's finding, tested by the standards used by the court, would seem to be entitled to no weight whatever as a matter of law.

In fact, the court's brief summary of the content of some of the "syndicate agreements" before him is a clear affirmative finding that they actually do contain all sorts of restrictive price and penalty clauses. Had the court understood the offense charged in the complaint, that is, that defendants have agreed to eliminate price-competition between themselves in the purchase and sale of securities and to channelize distribution, he would have seen how immaterial it is that each form was not identical with every other, or that defendant bankers were not the sole inventors of the system they use. It may, in fact, have been more effective to tailor each agreement differently, as to minor matters, to serve the alleged common purpose of eliminating price-competition.

Also, it is of more than footnote significance that the court failed here, as elsewhere, to notice that in almost every syndicate operation which he considered, from one to fifteen or more of the defendants, in addition to the manager, were parties to the syndicate agreements as participants. This was the strongest kind of evidence of association according to a common plan or "system." It was quite misleading, therefore, to suggest, as the court does, that each of the defendant firms acted entirely alone, "as separate entities," in the drafting and use of these agreements.

\section{No "Captive" Issuer}

With defendants' use of the syndicate method thus disposed of so handily, it might be expected that the court would next have examined the "triple con-
51. Ibid.
52. Ibid.
53. Id. at 684 .
54. Id. at 683 . 
cept" evidence. The first was a "means" alleged in Paragraph $44 A(1)$ of the complaint, the latter were "means" alleged in Paragraphs 44A(2), (3), and (4). But Judge Medina said that it would "put the whole case out of foctus" to do this, since in the absence of a showing of "substantial domination and control of issuers, as alleged, the 'triple concept' charge may come down to mere dialectics."65 Why this should be so, the court does not say, but it may have become apparent to him that if he went ahead to examine this evidence in isolation, as he had the syndicate method evidence, without regard to the price and channelizing charges of Paragraph 43 , it would be a quite meaningless thing to do.

At any rate, Part IV of the opinion is next given over to a consideration of whether the defendant bankers had combined for the purpose, as stated in the heading, of "Dominating and Controlling . . . the Financial Affairs of Issuers." This statement of the question immediately gives way in the text to "domination and control of $i$ ssuers by the 17 defendant firms acting in concert." 50 Moreover, it is fairly clear that the court felt it was incumbent on the Government to prove just that: "For, if issuers were free agents, they could always turn to any one or more of the dozens of other competent and well-equipped investment bankers, said to be eager to get the business but unable to do so bcause of the operation of the combination and conspiracy of the seventeen."

Quite evidently the court was again in search of a "unifying element." And, of course, if it could be shown that the seventeen actually did have the many issuers for whom they acted in their pockets, so to speak, then surely he would have something. But, while the complaint alleges, in Paragraph 25, that "[d]efendant banking firms frequently play an important part in the management of issuing companies ... and sometimes control the business affairs of an issuer," this was alleged merely as part of the description of the industry. It was not alleged as a "term" of the conspiracy, much less as a so-called "unifying element."

Nevertheless, the court now seized on this minor introductory allegation and inflated it into a main charge in the case. As he says, under the heading "Some Further Interim Observations": "the allegation of domination and control of issuers presents one of the fundamental and crucial controverted issues of fact in the case." "58 This idea, of "domination and control of issuers," seems to have obsessed the court. Apparently he regarded it as his function to show that the talk of monopoly and domination before the TNEC was without substance. At all events he sums up his consideration of the matter with the round statement that: "This record has not revealed a single issuer which can fairly be said to

55. Id. at 701 (italics added).

56. Ibid. (italics added).

57. Id. at 700. The court's point, if true, which is more than doubtful, would be relevant to the monopoly issue. It would have no bearing on the restraint of trade charge, that is, that defendants have agreed to eliminate price-competition between themselves and to channelize distribution.

58. Id. at 730 . 
be the 'captive' of any or all or any combination of these seventeen defendant firms." "פ9 Thus, having set up a straw man, the court lnocks him down with gusto. The central issue in the case was not "domination and control of issuers," but, as charged in Paragraph 43, whether the defendants were engaged in a way of doing business which had the purpose and effect of eliminating pricecompetition in the purchase and sale of securities and of channelizing distribution. This was pointed out to the court over and over again, with no apparent recognition on his part.

The evidence before the court had largely to do with directorships and was offered by the Government under Paragraph $44 \mathrm{E}$ (1) of the complaint. It is there alleged that one of the "means" employed by defendants "to influence and control the management and financial activities of issuers"-and hence to carry out the conspiracy charged in Paragraph 43-was this: "securing the appointment or election of directors . . . of issuers who, in addition to the performance of their duties, as such, would promote the interests of securing further underwriting business for the defendant banking firms."

Moreover, the evidence clearly established, what everyone knows to be true, that in many cases officers or partners of defendants have gone on the board of directors of issuers, thus giving their firms-and the syndicates they put together-a strong noncompetitive position in the subsequent purchase of the issuer's securities. But the court said: "No attempt was made to show the circumstances under which any of these men became directors," were material. And, he went on to say that "in many cases the men in question were invited by the management to come on the board," and many were men "of proven competence and judgment"-both matters not in controversy." Finally, since some of the defendants had many directorships and others few or none at all, he said that there was a complete "lack of any conspiratorial pattern."62

Of course, no "conspiratorial pattern" was ever charged at this level. W'hat the Government's statistical evidence did show was that, in the aggregate, where such interlocking relationships have existed, the directors' firms have managed or co-managed eighty-six percent of subsequent business. This was plainly strong evidence of a lack of any competition in the purchase of securities from such issuers, something defendants were charged with conspiring to bring about. ${ }^{63}$ The court, though, disregarded the point, and went on, at some pains,

59. Id. at 655. The court further says: "The myth of domination and control of issuers ... which was fostered by the ex parte TNEC proceedings ... should, perhaps, be given a decent burial and quietly laid to rest." Id. at 731. But surely the court is lacking in due respect, to say the least, in trying to bury so hardy a citizen-and with such haste-when he did nothing more serious than barely to get within the periphery of the case. The Government never undertook to show that any issuer was ever "captive" of any banker.

60. Id. at 708 .

61. Id. at 709.

62. Id. at 710 .

63. The court, mirabile dictu, turned this evidence upside down, at the prompting of defense counsel, and said these interlocking director relationships were really a device used 
to make up his own statistical tabulation. It showed the interesting, but irrelevant, fact that such business (where an interlocking relationship existed) accounted for only 12.5 percent of the total business managed by all of the defendants. ${ }^{64}$

\section{Traditional Banker}

Judge Medina deals at length with the evidence in support of Paragraph 44A (2), the "traditional banker" evidence. Part V of his opinion, under the heading, "The 'Triple Concept,' " is given over to it. But, to know what legal spectacles he used to view this evidence it is necessary to go back to that part of the opinion entitled, "Some Interim Observations." There, in speaking of defendants' use of the syndicate method, the court said: "If, on the important and fundamental phase of the case which has just been examined, there was no joint action nor any combination by the seventeen acting as a group, lack of such concerted action among them may likewise appear in other phases of the case as well." 65 After some further discussion of what to the Court was the "'triple concept' charge," 66 he decided first to dispose of the "dominance" allegations, as above discussed.

It is apparent, therefore, that when the court reached the traditional or regular banker evidence he had made the same error of law as in the other parts of the opinion already discussed. The complaint, Paragraph $44 \mathrm{~A}(2)$, does not charge that the defendants by "joint action" conspired in advance to recognize and defer to certain of their number as the "traditional" bankers for certain issuers. On the contrary, it merely alleges that the defendants do recognize and defer to the "claims" of traditional bankers, as only one of several "means" by which defendants are charged with having conspired to eliminate pricecompetition and to channelize distribution. But the court seems never to have been able to get hold of the basic charge of the alleged conspiracy, and so he pursued each alleged "means" to exhaustion, as if $i t$ were charged as the nexus of the conspiracy.

In this instance the court was able to reach over to Paragraph 45, dealing with "restrictive customs and practices," to lend credence to his point that the "triple concept" allegations, not Paragraph 43, must constitute the nexus of the conspiracy. Defendants are there alleged, by "concert of action," to "operate pursuant" to certain restrictive practices, including recognition of "traditional banker" and so on. Of course, to anyone familiar with pleading, that is a funny

by defendants "to further competition for investment banking business." Id. at 703. So, it seems, they gave no offense to the Sherman Act. Of course, long-term contracts giving the banker express, rather than tacit, control of future financing-as were once used in the industry-would have been an even more effective competitive "device," of the same sort. That is, they would not have been a competitive device at all, but a means of prevcnting competition for the purchase of securities and, as such, plainly unlawful. Standard Oil Company of California v. United States, 337 U.S. 293 (1949).

64. United States v. Morgan, 118 F. Supp. 621, 710 (S.D.N.Y. 1953).

65. Id. at 699 (italics added).

66. Ibid. (italics added). 
place to go for a statement of the offenses charged. The only "concert of action" having any bite in it is that charged in Paragraph 43. In other words, if defendants have in fact conspired to eliminate price-competition and to channelize distribution, it would make no difference whether they had concertedly employed each or any one of the "restrictive practices" or "means" alleged to have been employed.

Looking at the mass of traditional banker evidence as he did, however, the court was able to make this carefully worded finding: "I find that Morgan Stanley at no time 'adhered' to any 'practice' of 'traditional banker,' nor was Morgan Stanley at any time a party to any conspiracy or agreement on 'successorships,' nor to any 'code' having such or any similar provisions." same, in substance, is next found with respect to each of the other sixteen defendants.

It is evident, on the face of it, that this finding does not meet the Government's case. It is not a finding that MIorgan Stanley \& Co. has never and does not now at times recognize and defer "to the claims of traditional bankers to manage and control the merchandising of the securities of particular issuers," as alleged in Paragraph 44A(2). The court, in fact, could not properly have made such a finding on the evidence before him. For one thing, it would squarely contradict Stanley's own express declaration that: "If the business is satisfactorily done, it would be fair enough to think that the fellow who has it should keep on with it."68 Stanley's statement with much supporting evidence was offered-and urged throughout-as the plainest sort of proof that Morgan Stanley \& Co. does defer to the claims of traditional or regular bankers, provided, of course, the relationship is a satisfactory one. ${ }^{60}$ The evidence gave the court much trouble, as well it might: he finally disposed of it incorrectly, but with a great show of virtue, by saying the Government had "virtually abandoned the theory of the complaint," and was now, with many "twists and turns," urging such evidence as some sort of "lesser charge," which he certainly would not permit them to do.70

In the case of Kuhn, Loeb \& Co., the opinion also shows clearly that a finding of the sort required could not have been made. John Schiff, a partner and

67. Id. at 754.

68. Id. at 746. It would also contradict Stanley's basic view of the business, that it can best be done by private negotiation.

69. See Plaintiff's Rebuttal Brief of June 19, 1953, p. 9 et seq., United States v. Morgan, 118 F. Supp. 621 (S.D.N.Y. 1953).

70. United States v. MIorgan, 118 F. Supp. 621, 736 (S.D.N.Y. 1953). The court's further statement, that Government counsel had "insinuated" from the start that the defendants use "satisfactory relationship," "inheritance," and so on, as "double talk;" designed to "cover up" and "conceal their operations" like "bootleggers might use a sort of canting speech," id. at 734-5, would be very unfair to counsel, if it were not so fantastically wrong. These words zere used by the defendants, and, so far as the record shows, they mean just what any normal person would understand them to mean. It was the court, not Government counse., who was always concerned about "connivance," "double tall;", "slullduggery" and such things. Id. at 757 . 
a defendant in the case, testified upon deposition, subject to full cross-examination, that it was the policy of his firm not to go after business where the issucr had an established banking relationship. While the court brushed this testimony aside with the remark that it "must be read with some reservation," "1 it is surely evident that the court could not have found in the face of it, and the supporting evidence, ${ }^{72}$ that Kuhn, Loeb \& Co. has not deferred to the claims of traditional bankers, with the purpose and effect of eliminating price-competition. At all events, no such finding was made, either with respect to Kuhn, Loeb \& Co. or any of the other defendants.

The latter part of the finding, that no one of the defendants is "a party to any conspiracy or agreement on 'successorships,'" is likewise-for the reasons above stated-completely off center. No "conspiracy" on successorships was ever charged. But the bare fact that anyone should even make a claim to "successorship" in a truly competitive industry is surely unusual. This occurred at the time when the Glass-Steagal Act ${ }^{73}$ was passed and several of the bank security-affiliates, such as the Guaranty Company, went out of business. In the case of Guaranty, Swan and others went over to E. B. Smith \& Co. (now the defendant Smith, Barney \& Co.) and claimed-because of past relationship-that the business formerly done by the Guaranty Company was theirs. In many cases-though not all-these and other similar claims to "inheritance" were recognized, thus bearing out dramatically the traditional banker allegations of Paragraph $44 \mathrm{~A}(2)$.

It will be noted, in all this, that the first question, that is, whether continuing banker-client relationships do exist in the industry, is not in real dispute. The interlocking directorship cases, disposed of separately by the court, are a prime traditional-banker example, but the Government also put many others in evidence, where the relationship was only slightly less close. In some, as in the case of the Pacific Gas \& Electric Company account, there was an early contest for leadership. The court with great zeal brought these instances to the forein order that "light and air"74 might be permitted to enter-but saw no significance to the Government's point that in issue after issue thereafter the leadership remained unchanged, with no evidence of any further competition of the sort, much less of price-competition for the securities when ready for market.

71. Id. at 757.

72. Exhibit 117, Transcript of Record, United States v. Morgan, 118 F. Supp. 621. (S.D.N.Y. 1953), is a case in point. This was a memorandum, dictated by Schiff in regard to Armstrong Cork financing, in which he said: "I explained to Mr. Freeman that the Guaranty Company's successor was E. B. Smith \& Co., and that naturally we did not want to poach on their preserves." (Italics added.) The court turned this upside down also. See United States v. Morgan, 118 F. Supp. 621, 760-1 (S.D.N.Y. 1953). The evidence did not mean what it said, and what Schiff testified it meant. To the court, it was a very subtle illustration of how the Kuhn, Loeb "show window" method of "competition" worked. In plain words, of course, show window competition means that the firm does not engage in price-competition at all, even as charged.

73. 48 Stat. 162 (1933), 12 U.S.C. c. 2, 3, 6 (1952).

74. United States v. Morgan, 118 F. Supp. 621,807 (S.D.N.Y. 1953). 


\section{Historical Position and Reciprocity}

With "traditional banker" out of the way, the court made short work of "historical position" and "reciprocity." It is difficult, in fact, to say what the actual finding of the court is as respects the first, except that it appears from a short discussion under the heading, "Historical Position," that he regarded the allegations of the complaint to have been disproved. ${ }^{75}$ In the case of reciprocity, the discussion is even briefer, but the basis for the court's finding is made quite explicit: "Were there some uniformity or some common pattern the case would be different. As it is, there is a pattern of no pattern; and I find that, considering all the evidence in the record, including the stipulated statistical data, the reciprocity charge has been disproved."io

Here again Judge Medina could not properly have made a finding to controvert the Government's case, that is, he could not have found that the defendants have not reciprocally exchanged participations in the buying groups which they manage, as alleged in Paragraph 44A(4). For the evidence showed, as the court noted, that some of the defendants have kept reciprocity records. ${ }^{77}$ And, at least two witnesses testified on deposition, subject to cross-esamination, that their firms $d o$ award participations-where there is a place openon the basis, in part, of business received from other bankers, or expected in the future. ${ }^{78}$ The statistical data also showed that a very large part of the participation business done by the defendants was received from each other. All of this was simply disregarded to make the interesting, but immaterial, finding that "there is a pattern of no pattern." Pattern in a price-conspiracy case, or in any other for that matter, is not essential, or even to be expected, at a "means" level.

Probably the "historical position" evidence was found wanting upon much the same basis. It, too, failed of a perfect pattern, though there was a remarkable amount of substantial similarity. The court, however, went on to point out that " 'claims' based on 'historical position' are made throughout the industry as a whole, and not by any single group, such as the seventeen investment banking houses made defendants in this case."79 But this reason was no better than the first, since, as above discussed, the circumstance that other industry members may likewise assert "historical position" is entirely consistent with the Government's restraint of trade case. ${ }^{80}$ Indeed, it greatly strengthens it.

75. Id. at 738.

76. Id. at 633 (italics added).

77. Ibid.

78. These were C.E. Mitchell of Blyth \& Co., Inc., and Monroe Gutman of Lchman Brothers, both of whom testified with commendable frankness. Transcript of Record, pp. 10,976, 10,897, United States v. Morgan, 118 F. Supp. 621 (S.D.N.Y. 1953).

79. United States v. Morgan, 118 F. Supp. 621,739 (S.D.N.Y. 1953).

80. The fact that a practice is industry-wide has been held many times not to negative a charge that particular members of the industry are engaged in a conspiracy in restraint of trade. Among the cases cited to the court were: Butterick Co. v. Federal Trade Comm'n, 4 F.2d 910, 911-2 (2d Cir.), cert. denied, 267 U.S. 602 (1925); Schine Chain Theatres, Inc. 
Affirmatively, what the court has done in this part of his opinion is to find that defendant bankers do make claims to "historical position" and that, as managers, they do recognize such claims on the part of others in numberless cases. Also, that defendants, whether as a "polite refusal" or otherwise, have denied participations-or denied an increased participation-to many bankers who do not have historical position. ${ }^{81}$ Moreover, this was done by the defendants, not the issuers, for as the court further states: "While it is difficult to generalize on the subject, however, it seems to me that the issuers more or less left it to the manager to make up the group, as the manager would be in a better position to know who should be included."82 In other words, the court found affirmatively exactly what the Government alleged in Paragraph 44A (3) of the complaint.

This part of the opinion, properly understood, is even more favorable to the Government. For Judge Medina goes on to say that while the documents "are full of such words as 'claims' and 'rights," "83 nevertheless: "The competition for participations in the various underwritings, and to some extent even for positions in the selling groups, is intense . . ."84 It seems, moreover, that: "There is a good deal of dissatisfaction with the participations which are finally allotted and practically every investment banker seems alway's to be using various arguments to get a better position than before, or at least a position which is no worse than before." 85

It must surely have been evident to the court that a mere scramble for positions in a syndicate is not price-competition. If anything, it is competition not to have price-competition. Were there real price-competition those bankers dissatisfied with their position in the historical group, or some of them, would join with others, and themselves offer to buy the issuer's securities, ${ }^{80}$ as is done almost every day in the case of competitive bidding. So, far from having disproved the Government's case, therefore, the court actually found in its favor, not only that "historical position" is used as alleged, but that "practically every investment banker" prefers to cling to an unsatisfactory "position" rather than offer price-competition. ${ }^{87}$

v. United States, 334 U.S. 110, 118 (1948) ; and, of course, United States v. Dennis, 183 F.2d 201 (2d Cir. 1950), aff'd, 341 U.S. 494 (1951).

81. United States v. Morgan. 118 F. Supp. 621,740 (S.D.N.Y. 1953).

82. Id. at $739-40$.

83. Id. at 738 .

84. Ibid. (italics added).

85. Ibid.

86. Even at the risk of being called "stinkers."

87. This finding actually cuts the ground from under the defendants' use of the syndicate. Erstwhile competitors may properly combine to buy an issue, where that is necessary because of insufficient capital,-or perhaps for other reasons, but where each participant could have taken a much larger share of the issue than he got, it is pretty plain that they have gone beyond the line. The syndicate then becomes a simple combination in restruint of trade. Nor is there any doubt as to the correctness of the court's finding, for it is also supported by the "historical position" evidence. In many cases a group which may have 


\section{Some Interim Observations}

It is time to take stock. The court has now, in just short of 200 pages, disposed of most of the Government's case, without finding anything whatever to support it. Of what remains, only the competitive bidding evidence-which the court seems also to have put off to one side in his thinking-will require comment. It is in order, therefore, to look briefly at hozi the court disposed of the case. It is apparent, at once, whether one is familiar with antitrust law or not, that the court never looked at the case as a whole; indeed, he could not very well have done so, for he was always off on a quest for some sort of "unifying element," in disregard of the charges stated in Paragraph 43.

Counsel, on both sides, told the court many times that he could not properly dispose of a conspiracy case piece-meal. It would not do to look separately at "traditional banker" and each of the various "means" alleged in the complaint, and then to throw them out one at a time. But, with disarming frankness, Judge Medina made it clear in his opinion that he did not agree: "There is much to be said in support of this reasoning; but the converse of it is equally sound. As each of these several props to the Government charge is disproven and thus eliminated, the structure as a whole finds less and less support." ${ }^{88}$ That may truly be an effective way to pull down a structure, but it is not an accepted way to try a conspiracy case. In fact, it was gross error. ${ }^{80}$

The court's error carried over even into the day by day receipt of evidence. Again, it was carefully explained to him, ad nauscam, that evidence in a circumstantial case of conspiracy can best be regarded as forming a "mosaic": that in the nature of the case the picture does not become clear until all the evidence is in. But Judge Medina would not be put off in that way; he felt he must make a microscopic examination of each item as it was introduced. As he said:

"Don't forget that the pieces of the mosaic are constantly forming. The talk about putting the mosaic together at the end of the case means putting true, accurate factual pieces together after the controversy on the facts has been resolved as to each piece. So you must not think that $I$ am going to wait until perhaps a year from now to decide out of a huge welter of proof what are the pieces to be put together, and it seems to me that is one of the things that the prosecution here has not paid due attention to. They have assumed that they are right on every one of these pieces, but if as to a substantial number

had to strain its resources to do a large issue is held together later even for quite small issues.

88. United States v. Morgan, 118 F. Supp. 621, 699-700 (S.D.N.Y. 1953) (italics added).

89. Among the many cases on the point are: American Tobacco Co. v. United States, 328 U.S. 781, 809 (1946) ; United States v. Patten, 226 U.S. 525, 544 (1913); Swift \& Co. v. United States, 196 U.S. 375, 396 (1905). Mr. Justice Van Devanter, in the Pallers case, made the point this way: "It hardly needs statement that the character and effect of a conspiracy is not to be judged by dismembering it and viewing its separate parts, but only by looking at it as a whole." 
I find the little piece to be black instead of white, how is it going to fit in?"00

Later in the case Judge Medina gave another illustration of what he was doing. He was piling up the evidence like "stones," he said, some of which might go "in the mosaic," and some not. Of course they had to be "real" stones, that was a point he was going "to be scrupulous on." Then, continuing, "I have a little pile on one side and a little pile on the other side of my mind, one that represents piles of real stones and the other represents a pile of stones that have collapsed and are to be more or less disregarded, then I have got the ones that I figure are real stones, and we will see what they make."91

As we have seen, they made nothing at all. If one may judge from the opinion, the pile of stones in the court's mind which might fit into a conspiracy mosaic was practically non-existent. Not even one little stone seems to have survived the process. But, surely, it is evident that the attempt to pass upon each item of evidence for accuracy, as it came in, and then, at that time, to take the next step also, and to pile it on one side or the other conspiracy-wise, was flagrant error. A court may no more properly make a piece-meal disposition of evidence, item by item, than he may knock out the various means alleged in the complaint, prop by prop.

\section{Competitive Bidding}

Judge Medina showed very little interest in the Government's evidence on competitive bidding when he reached it. Having, to his satisfaction, knocked the "props" out from under the "integrated over-all conspiracy," there apparently was not much left to do. At any rate, Part VI of the opinion is brief, a mere six or seven pages, and quite discursive. But the court does say that the defendants were not shown to have been engaged in a conspiracy to oppose competitive bidding: "we shall find that here again there was no joint action whatever by any conspiratorial combination."02 Since no conspiracy was ever charged at that point, even this statement might as well have gone unsaid.

The Government's evidence, as a matter of fact, was quite interesting, for it dealt with the long fight which the defendants have put up against "shopping around," 93 as well as "competitive bidding." That is to say, it got directly at

90. Transcript of Record, pp. 8318-9, United States v. Morgan, 118 F. Supp. 621 (S.D. N.Y. 1953). For a discussion of the art of making mosaics during the middle ages, if that has any point, see RoBB \& GARRISON, ART IN THE WeStern WorLd, 113 ct scq. (1942).

91. Transcript of Record, p. 18,325, United States v. Morgan, 118 F. Supp. 621 (S.D. N.Y. 1953). For other illustrations see id. at 10,286 and 12,439 .

92. United States v. Morgan, 118 F. Supp. 621, 817 (S.D.N.Y. 1953).

93. "Shopping around" is an informal way by which an issuer may get competing price offers. The evidence showed that the defendants were even more opposed to it, than to public sealed bidding. But the court saw no significance in that: "My own conclusion is that the machinery of 'shopping around,' which favored the less scrupulous bargainer, had little to commend it." Id. at 821 . Of course it is not uncommon for an issuer, when 
the question whether, as charged in Paragraph 43 of the complaint, the defendants actually have developed their way of doing business with the purpose and effect of eliminating price-competition and channelizing distribution. Moreover, contrary to the impression given by the court, each of the defendants, singly and in combination, was shown to have had a part in the conflict. ${ }^{34}$ Thus, far from being a matter to be dismissed easily, with the oft-repeated comment that the contentions of Government counsel "stem from a misconception of the investment banking business,"95 the evidence dealt with the heart of the case.

The highlight was the "campaign" of Eaton and Stuart, investment bankers, together with Robert $\mathrm{R}$. Young, railroad issuer, to bring about competitive bidding. The team was a good one. Faced with a history of twenty-five years or more in which only two firms, that is, either Kuhn, Loeb \& Co. or J. P. Morgan \& Co. (and later Morgan Stanley \& Co.), had managed substantially all railroad financing, there was not much chance for a competing banker to have any part in this business. But Young made it clear in connection with the $\$ 30,000,000$ of financing for the $\mathrm{C}$. \& $\mathrm{O}$. in 1938, that his railroad, at least, wanted price-competition. ${ }^{96}$ And, in that case, the business finally went to the Stuart-Eaton syndicate, at a saving of thousands of dollars over the price quoted by Stanley and Walker on behalf of the traditional bankers. ${ }^{07}$

But the court was not impressed. In fact, to him, the whole thing was "an unsavory subject," about which "the less said ... the better." ever, discuss one "unsavory" episode, that dealing with the financing for the Terminal Railroad Association of St. Louis in 1939.93 There the regular bankers, Morgan Stanley \& Co. and Kuhn, Loeb \& Co., had worled out privately the terms of a proposed bond issue, all without fee, in expectation of later buying the issue and distributing it at a profit. It was at this point, that Young, on behalf of one of the constituent carriers, demanded price-competition, even as contemplated by Congress when it passed the Sherman Act. And, after a considerable campaign, ${ }^{100}$ he succeeded, the regular bankers withdrew, and the issue went to competitive bidding.

negotiating with a syndicate, to get "price views" from commercial bankers and others familiar with market conditions, but that is not spoken of as "shopping around," nor is it "price competition."

94. For one thing, each of the defendants was a party to one or more briefs in opposition to competitive bidding.

95. Id. at 817 .

96. The whole story, under the title, A Strange Alliance for Monopoly, is told by Young in the Atlantic Monthly for December, 1946. The substance of his account was put in evidence, but, while the court said it "deserves description," he chose to "pass it by." United States v. Morgan, 118 F. Supp. 621, 818 (S.D.N.Y. 1953).

97. There was a question of fact whether an actual "bid" was made for the securities, or whether Stanley and Walker merely quoted a price. Ibid. For present purposes it malies little difference; there is no gain-saying the point that a price was quoted.

98. Ibid.

99. Id. at 819.

100. The court speaks of this as "a campaign of misrepresentation," of "misstatements of fact," and even of "vituperation," id. at 818-19, but points to no evidenee in the record, 
This episode, too, did not impress the court. At least not favorably. Perhaps he simply missed the point, for he said: "While there is doubtless much to be said on each side ... it is clear to me that it is no part of my function to pass on the merits of the controversy over public sealed bidding; and I shall not do so."101 Of course, the court was never asked to pass on the merits of competitive bidding; but he was asked over and over again to view defendants' opposition thereto for its bearing on the central charge of the complaint, that is, that defendants had conspired to eliminate price-competition and to channelize distribution. The opinion gives no sign that the court ever so examined the competitive bidding evidence.

The plain fact is that the defendants' continuing-banker way of doing business could not weil exist in the face of price-competition. The competitive bidding evidence shows this rather plainly. In numberless cases the traditional group-for all its supposed familiarity with the issuer's affairs-has been unable or unwilling to pay as much for the issuer's securities as a competing syndicate. ${ }^{102}$ Moreover, the management fee has had to be reduced from, say, one-quarter point to a mere five percent of the spread, or has been dropped altogether, and spreads in turn have been greatly narrowed. ${ }^{103}$ It would seen, therefore, that instead of being an "unsavory" subject, to be summarily dismissed, the competitive bidding evidence should have been very persuasive, indeed.

\section{Plan or Business Necessity}

It was common ground between court and counsel that "the Sherman Act was not designed to compel businessmen in any industry to compete in any particular way."104 The Act is directed at restraints. But it was easy for the defendants to say next-as they did quite often-that competitive methods are necessarily different in the securities business on Wall Street than, say, in the clothing business on Grand Street. ${ }^{105}$ Thus a trap was laid. If it should appear that there was some competition-however polite-in the securities

nor is there any, to support such intemperate charges. The campaign no doubt was distasteful to the defendant bankers, but the evidence indicates that so also is price-compctition of any sort. Young's announced purpose was to reduce costs, still a quite respectable objective.

101. Id. at 819 .

102. The most dramatic illustration, perhaps, is the A.T. \& T. financing. Prior to 1941 , when the company went to competitive bidding, J. P. Morgan \& Co. (and later Morgan Stanley \& Co.), as the company's bankers, had managed issues aggregating in the ncighborhood of $\$ 2,000,000,000$. Since then, not only have financing costs been greatly reducedfrom a spread of two points or more to less than one-half at times-but the Morgan Stanley $\&$ Co. syndicate has been outbid on many occasions.

103. This appeared in the statistical evidence not discussed by the court. For a general study of the matter, see Peterson, Negotiated vs. Competitive Debt Financing, 1 VAND. L. REv. 531 (1948).

104. United States v. Morgan, 118 F. Supp. 621, 738 (S.D.N.Y. 1953).

105. See, e.g., Transcript of Record, p. 22,797, United States v. Morgan, 118 F. Supp. 621 (S.D.N.Y. 1953). 
business, that would suffice $;^{106}$ the absence of any other must be due to the necessities of the business, which Government counsel were said not to understand anyway.

Perhaps it was the court's acceptance of this argument, fallacy and all, which accounts for his strange disregard of the price-competition charge. The opinion is replete with references to competition at some point or other for leadership, and the competition is said to be "intense" for positions in buying groups, but one may search the opinion from stem to stern without finding more than one or two brief references to price-competition on the part of the defendants. There being virtually no competition of the sort-aside from public sealed biddingthe court may simply have regarded that fact as one of the natural conditions of the business. ${ }^{107}$ It just happened that way, perhaps.

The court virtually says as much. Half way through the opinion, under the heading, "The "Master Mind," " he makes this comment : under "the old, established way of conducting the investment banking business, which had slowly grown up functionally over the years," the "major part of the competitive effort of investment bankers generally was devoted to an attempt to establish relationships with issuers." 108 That is, to the establishment of continuing banker-client relationships, even as the Government had alleged. But, even here, a banker does not seek to push hinsself in ; rather, he waits to be "invited." Then the court leaps to the conclusion: "That is why there is so little price competition after the issues have been shaped up ...."109 And. that is the end of the matter; the business simply is not done that way.

It is odd that so astute a judge as Judge Medina did not see through such nonsense, a standard defense technique. ${ }^{110}$ Stanley certainly made his attitude toward price-competition explicit enough. In the letter-not discussed by the court-which Stanley wrote upon withdrawing from the St. Louis Terminal business, he said, in part: "We believe that terms arrived at through direct negotiations between the borrowing corporation and its bankers, selected by it as competent judges of credit and of market conditions, are more likely to be right than those arrived at in the heat of a competitive struggle of dealers to overreach each other in the desire for business." Such "competitive methods,"

106. By happy chance even the "show window" competition of Kuhn, Loeb \& Co. could meet this test. See United States v. AIorgan, 118 F. Supp. 621, 7547 (S.D.N.Y. 1953).

107. In Exhibit 198, Transcript of Record, United States v. MLorgan, 118 F. Supp. 621 (S.D.N.Y. 1953), Stanley makes the same point, but he goes one step farther: "I grant right off the bat that there is not the same kind of competition in the financing of securities as there is in bricks and mortars and shoes, and whatever else. I don't belice's there should be. I don't think it is appropriate." (Italics added). This statement was made at a hearing before the SEC in 1941. The Commission was seeking to determine whether there was full competition for the purchase of public utility securities, and decided in the negative. Rule U-50 was the outcome.

108. United States v. Morgan, 118 F. Supp. 621,747 (S.D.N.Y. 1953).

109. Ibid. (italics added).

110. One of the best illustrations of the strategy is United States v. Aluminum Company of America, 44 F. Supp. 97 (S.D.N.Y. 1941), rev'd, 148 F.2d 416 (2d Cir. 1945). 
he continued, "tend to overpricing the issue to the investor and to subsequent dissatisfaction and loss of credit and goód will of the borrower."111 And, he might have added, give a less sure profit to the bankers.

Here was no illusion that the defendants' traditional-banker way of doing business-without price-competition-is merely the result of "functional" growth over the years. It was the defendants-not necessity-who carefully nurtured the ideas that the banker occupies a dual role, as professional adviser, and also as merchant; and that any banker would be doing an unfriendly act to interfere with the first role, while, as to the second, the issuer does not really want the last penny for his securities anyway. So, if the result has been no price-competition, and only a minimum of plan-competition, with securities flowing issue after issue in the same general channels, it must have been the defendants who "planned it that way." Who else?

Stanley, in fact, would have the banker occupy still a third role, that of "umpire."112 It should also be the banker's function, he said, to see to it that terms are "right,"113 in order to protect investors. The evidence before Judge Medina-not referred to by him-showed that this meant, as a matter of dollars and cents, that the public offering price should be so set that, upon distribution of the securities, they would appreciate in price by, say, one-eighth or perhaps a quarter point, ${ }^{114}$ something quite impossible to bring about in a truly competitive market. However laudable this plan might be, it too was plainly not a matter of necessity. And, quite as plainly, it violated the congressional com-

111. Copy of letter from Stanley to Terminal Railroad Association of St. Louis dated July 5, 1939, Exhibit 193, Transcript of Record, United States v. Morgan, 118 F. Supp. 621 (S.D.N.Y. 1953) (italics added). Judge Medina, no doubt facetiously, has commented elsewhere: "When you write an opinion no one can make you put in something you want to leave out. You can readily see how this simplifies the process." Medina, Bcforc Ascending the Bench-and After, 29 MIcr. ST. BAR J. 5 (1950). And again in 1952 he said: "Anyway, this opinion writing has a perfect fascination for me. Part of the joy is that no one can make you put in something that you want to leave out." Medina, Some Reflections on the Judicial Function: A Personal Viewpoint, 38 A.B.A.J. 107, 109 (1952).

112. Exhibit 85, introduced on May 24, 1951, Transcript of Record, p. 7613, United States v. Morgan, 118 F. Supp. 621 (S.D.N.Y. 1953). Speaking of private placements, Stanley said they caused "the loss of whatever value there is-and we think it is substantial -in having a third party, i.e., the investment banker, stand as an umpire between the borrower and the investor." (Italics added).

113. Exhibit 193, supra note 111.

114. This was testified to by Swan and also, in substance, by Sachs. Transcript of Record, p. 17,790, United States v. Morgan, 118 F. Supp. 621 (S.D.N.Y. 1953). Later, when Stanley was asked whether it was the practice of his firm to price an issue so that it would appreciate during the first four weeks or more of its distribution, he said: "The answer is no. We did not know what it was going to do in the market." As a matter of practice, however, a tabulation before the court (which had been prepared by Stanley's firm) showed that in the five year period, 1936-1940, with respect to a total of some $\$ 2,000,000,000$ of securities managed by Morgan Stanley \& Co., there had been a small average appreciation in each of the four weeks following the public offering. See Transcript of Record, p. 7126, United States v. Morgan, 118 F. Supp. 621 (S.D.N.Y. 1953). 
mand, that the market, not a banker in the guise of umpire, should determine when prices and terms are fair and right.110

\section{Some Final Observations}

It has not been possible to consider in much detail whether the Government actually made out a prima facie case, as seems to be true. Necessarily, the inquiry has had to deal largely with the preliminary question, whether the court ever ruled upon the case as alleged in the complaint, and as presented in evidence. With all due respect to the learned court, the answer to that must be no. It would be hard, in fact, to conceive of any more flagrant error of law than the court committed, when, in disregard of the "cliarges" set forth in Paragraph 43, he proceeded to dispose of the several "means" alleged in the complaint in piecemeal fashion, each in turn as if it were the offense charged. The case must necessarily have been reversed on appeal.

This raises the question: Why was no appeal taken? The case plainly was not the "lost cause," that Judge Barnes said it was. And, surely, he must have understood that, as a precedent, the case would greatly encourage the defendant bankers in their noncompetitive ways of doing business. What the decision will mean to the industrial issuer who might wish to sell his securities in a truly competitive market is impossible to say. But, to the extent that the reduction in banker's fees brought about by compulsory competitive bidding in the utility field is an index, it may well run into millions of dollars. The Government's inaction, also, must have brought "joy" to the bankers.

On the resale side, too, the decision can only result in mischief. All of the hundreds of price maintenance clauses, penalties, stabilization practices, and so on, which were before the court, were held to be lawful, without any exception. True, this part of the opinion was, amazingly enough, labelled "dictum."110 And, it was recognized that some practices "in the future" as "in the past" might be unlawful. ${ }^{117}$ But, nevertheless, the court ruled broadly that: "the fixed-price type of public offering of new securities viewed in the large, and on the basis of methods now in common use by the investment banking industry, gives no offense to the Sherman Act."118

Judge Medina had two legs to his argument. The first, that resale price maintenance agreements, penalty clauses, and such are all within "the rule of

115. In the days prior to the SEC it definitely was the role of the investment banker, as Stanley says, to take public responsibility for the character of the securities he brought out. And, of course, it still is, but in much lesser degree. It was largely because Congress felt that the banking fraternity had failed in that role that the Securities Act was passed. Today the investor-and syndicate members as well-have far more accurate information available to them concerning a new security than they ever had before. For the same reason it may now be time to recognize that the old hand-tailored, continuing-banker way of marketing securities, as a professional service, must give way to a less costly, more competitive, large scale merchandising operation.

116. United States v. Morgan, 118 F. Supp. 621, 6S6 (S.D.N.Y. 1953).

117. Id. at 691 .

118. Ibid. 
reason," as declared by the Chicago Board of Trade ${ }^{110}$ case, need not detain us. It openly flouts the many later cases, ${ }^{120}$ properly called to his attention, which have said, with emphasis, that any tampering with price is per se illegal. ${ }^{121}$ But the second leg should have given the Assistant Attorney-General even more concern. This was the contention that the Securities Act and related legislation have wholly exempted the investment banking industry from any need to comply with the Sherman Act, ${ }^{122}$ at least in the resale price area. Probably the court here too was wrong, for "implied repeals" have not been regarded favorably by the Supreme Court. ${ }^{123}$ But, whether so or not, as a matter of orderly government, questions of such importance surely should not be left in unnecessary doubt.

In short, the Government appears to have had no rational basis for its failure to file an appeal. It would have been in the public interest, it seems, if only a single issue of procedure had been brought up, that is, whether any trial court can accord the plaintiff a fair trial, if, before the plaintiff has had an opportunity to offer any evidence whatever, the court listens, as Judge Medina did, for nearly four months to opening statements by defense counsel. ${ }^{124}$ The Government's action in quitting here too, without firing a shot, must surely plague antitrust law for some time to come.

119. Chicago Board of Trade v. United States, 246 U.S. 231 (1918).

120. See Kiefer-Stewart Co. v. Seagram \& Sons, 340 U.S. 211 (1951), and cases there cited.

121. The point is ably discussed in Note, The Investment Bankers Case: The Use of Semantics to Avoid the Per Se Illegality of Price Fixing, 63 YaLE L.J. 399 (1954).

122. The court said: "The plain truth of the matter is that the legal questions now under discussion form an area of head-on collision between the SEC on the one hand and the Antitrust Division of the Department of Justice on the other." United States v. Morgan, 118 F. Supp. 621, 694 (S.D.N.Y. 1953).

123. See, e.g., United States v. Borden Company, 308 U.S. 188 (1939). In fact, Judge Medina agreed, for he said that the Securities Act did not give "an implied exemption in whole or in part" from the Sherman Act. United States v. Morgan, 118 F. Supp. 621, 697 (S.D.N.Y. 1953). But he then went on to say without any support from the record, aside from the assertions of defense counsel, that: "The real point is that all those who worked together on the formulation of this most significant and beneficial legislation went about their task of integrating into the statutory pattern the current modes of bringing out new security issues then in common use by investment bankers generally, with complete assurance that no violation of the Sherman Act was even remotely involved." There was thus no implied exemption, which is bad, but merely an implied approval, which to the court, apparently, was something very different.

124. The court did a good job in having the plaintiff's proposed exhibits printed in advance of trial, and approved by defense counsel as to genuineness. That saved much court room time. But it was surely reversible error to permit, if not encourage, defense counsel thereafter, in their opening statements, to range far and wide to explain them away. The time honored practice has been for the plaintiff first to put in his case, when it can be seen as a whole. The defendants then have their day in court, when their case can be made out with admissible documents and sworn testimony subject to cross-cramination. 